\title{
Purchase Decision pada E-commerce Tiket Travel dan Reservasi Hotel di Indonesia
}

\author{
Bambang Eko Samiono ${ }^{1}$, Ulfa Mustikarini Hanifati ${ }^{1}$ \\ ${ }^{1}$ Program studi Manajemen, Fakultas Ekonomi, Universitas Al Azhar Indonesia \\ Jalan Sisingamangaraja, Kompleks Masjid Agung Al Azhar, Kebayoran Baru, Jakarta Selatan 12110 \\ Penulis untuk Korespondensi/E-mail: be.samyono@uai.ac.id
}

\begin{abstract}
This study aims to determine the effect on Purchase Decisions by Web Quality and EWOM through Online Trust on three objects of travel ticket service websites and online hotel reservations in Indonesia (Traveloka.com, Tiket.com, and Pegipegi.com). The technique of taking this research is non-probability sampling, and purposive sampling, which is the technique of determining the sample with certain considerations. The sample used in this study is respondents who have made transactions on travel ticket services and online hotel reservations in the last 3 months in the areas of Jakarta, Bogor, Depok, Tangerang, and Bekasi with 200 people and analyzed using SEM. From this study, it can be concluded that Purchase Decision is only directly affected by Web Quality. While Online Trust is directly influenced by Web Quality and EWOM, however, there is no direct influence of Online Trust on Purchase Decision. There is also no indirect effect of Web Quality and EWOM on Purchase Decisions through Online Trust.
\end{abstract}

Keywords: Web Quality, EWOM, Online Trust, Purchase Decision.

\begin{abstract}
Abstrak
Penelitian ini bertujuan untuk mengetahui pengaruh Purchase Decision berdasarkan Web Quality dan EWOM melalui Online Trust pada tiga objek website layanan tiket travel dan reservasi hotel online di Indonesia (Traveloka.com, Tiket.com dan Pegipegi.com). Teknik pengambilan sampel penelitian ini adalah non-probability sampling, dan purposive sampling. Ampel yang digunakan dalam penelitian ini adalah responden yang pernah melakukan transaksi layanan tiket perjalanan dan reservasi hotel secara online dalam 3 bulan terakhir di wilayah Jakarta, Bogor, Depok, Tangerang dan Bekasi dengan jumlah 200 orang dan dianalisis menggunakan SEM. Dari penelitian ini dapat disimpulkan bahwa Purchase Decision hanya dipengaruhi secara langsung oleh Web Quality. Sementara Online Trust secara langsung dipengaruhi oleh Web Quality dan EWOM, namun tidak ada pengaruh langsung Online Trust terhadap Purchase Decision. Juga tidak ada pengaruh tidak langsung Web Quality dan EWOM terhadap Purchase Decision melalui Online Trust.
\end{abstract}

Kata kunci: Kualitas Web, EWOM, Kepercayaan Online, Keputusan Pembelian.

\section{PENDAHULUAN}

Perkembangan industri travel dan perhotelan (penginapan) di Indonesia saat ini makin meningkat, seiring pertumbuhan jumlah peminat perjalanan wisata yang makin menunjukan angka peningkatan yang signifikan.
Arief Yahya selaku Menteri pariwisata mengemukakan bahwa, daya saing pariwisata Indonesia ditingkat internasional telah berada di peringkat 50, dimana tahun-tahun sebelumnya hanya berada pada level bersaing hingga peringkat 70 saja (KEG, 2018). Hal tersebut mengindikasikan bahwa industri pariwisata di 
Indonesia dalam tahap perkembangan pesat ditandai dengan persaingan yang semakin ketat. Tentunya, perkembangan tersebut tak luput dari dukungan perkembangan teknologi informasi dimana memiliki pengaruh yang sangat luar biasa pada perilaku konsumen dalam informasi yang cepat dan akurat mengenai hal hal yang berkenaan dengan industry kepariwisataan.

Digital sales di Indonesia mengalami peningkatan dimana di tahun 2014 sebesar $\$ 4,26$ juta dan tahun 2017 sebesar \$10,54 juta dengan pertumbuhan yang paling tinggi di Asia Pasifik hingga 44\% ditahun 2014 dan perlahan turun hingga 14.2\% di tahun 2017 (KEG, 2018). Meskipun pertumbuhannya melambat namun bila dilihat market share-nya mengalami kenaikan yang cukup signifikan pertahunnya. Dari data-data terlihat pula bahwa area bisnis ticketing dalam ecommerce cukup mempunyai potensi yang besar. Dan studi mengenai hal inipun cukup menarik untuk diteliti. Salah satu yang lebih dalam dicermati adalah mengenai faktor-faktor yang memicu timbulnya pembelian di situs tiket travel dan reservasi hotel. Seperti diantaranya penelitian Sastika (2016) yang meneliti mengenai purchase decision pada salah satu situs tiket travel dan reservasi hotel.

Kemudahan yang ditawarkan oleh online shop merupakan salah satu alasan utama dari pergeseran perilaku dari offline ke online. Namun di sisi lain banyak juga faktor-faktor yang menyebabkan pelanggan untuk enggan menggunakan e-commerce, karena adanya masalah risiko, yang umumnya terkait seputar keamanan dalam pembayaran, ketakutan akan penipuan, ataupun kualitas barang yang tidak sesuai ekspektasi (Kotler \& Keller, 2016). Untuk itulah peranan kualitas website menjadi sesuatu yang mutlak diperlukan untuk meningkatkan kepercayaan konsumen.

Konsumen cenderung memiliki sikap membaca ulasan online atau electronic word of mouth (EWOM) sebelum membeli/menggunakan suatu produk/jasa, kemudian mengunggah ulasan mengenai pengalaman setelah menggunakan barang/jasa tersebut. Pada umumnya diperoleh data sekitar $61 \%$ pembeli akan membaca ulasan online sebelum membuat pemesanan suatu produk atau keputusan pembelian. Sedangkan di Indonesia, studi yang dilakukan terhadap produk ponsel diperoleh data ada sekitar $95 \%$ pembeli ternyata $70 \%$ nya mengkaji suatu produk atau layanan melalui ulasan online pelanggan lain walaupun disampaikan oleh konsumen yang tidak mereka kenal (Gilliland, 2017). Sementara Bright Local melansir, sekitar $74 \%$ pembeli mengungkapkan jika ulasan positif membuat mereka akan semakin mempercayai produsen tersebut, maka semakin tinggi kepercayaan pembeli pada sebuah produsen tentu akan mendorong mereka untuk membeli produk dari produsen tersebut.

Penelitian ini akan mempelajari mengenai pengaruh Website Quality dan eWorm pada Purchace Decision pada E-commerce tiket travel dan reservasi hotel melalui Online Trust. Penelitian ini memperbaharui penelitian sebelumnya dengan memilih 3 obyek $E$ commerce yang mempunyai kesamaan dalam pelayanan jasa yang diberikan. Yaitu Tiket.com, Traveloka.com, dan Pegipegi.com dimana ketiganya sama sama menyedikan tiket pesawat, Kereta api serta melayani reservasi hotel di Indonesia. Selain itu penelitian ini dilakukan dengan analisis SEM.

\section{Web Quality}

WebQual telah dikembangkan sejak tahun 1998 dan telah mengalami berbagai iterasi dalam penyusunan butir-butir pertanyaannya. Hingga pada akhirnya WebQual versi 4.0 yang disusun berdasarkan pada penelitian tiga area yaitu: kualitas informasi dari sistem informasi, kualitas interaksi dan usability dari human computer interaction. (Sastika, 2016, 18 - 19 Maret). Indikator yang digunakan dalam variable ini adalah (Sugianto, 2016): Information (Informasi), Ease of Use (Kemudahan Pemakaian), Fullfilment/Reability (Reliabel), Site Design (Desain Situs), Security/Privacy (Keamanan) dan Interactivity (Pelayanan Interaktif).

Menurut Lee, Wu, Lin \& Lee (Nasiruddin, Kauthar, Hashim, \& Yusof, 2016) dengan dukungan teknologi modern, kini siapa saja bisa mengunggah informasi melalui internet dengan mudah. Memanfaatkan kemudahan tersebut, tentunya kadar konsumen dalam mengunggah ulasan secara online juga meningkat, sehingga EWOM dapat memengaruhi perilaku konsumen dalam pengambilan keputusan pembelian. Masih sedikit dari konsumen yang sadar bahwa dengan mengunggah ulasan ke internet sama 
saja dengan mereka melakukan strategi pemasaran bagi perusahaan dari produk/jasa yang bersangkutan. Produk/jasa dengan EWOM yang positif cenderung akan menumbuhkan minat pembelian yang baik pula dari konsumen. WOM Intensity (Intensitas WOM), Opinion Valence (Komentar) dan Content (Konten) digunakan untuk mengukur indicator (Sugianto, 2016).

\section{Online Trust}

Menurut pendapat yang dikemukakan Zur, et al. (2012) (Setyawan \& Japarianto, 2014) kepercayaan adalah salah satu faktor penting dalam pembangunan berkelanjutan, mendorong hubungan jangka panjang antara mitra bisnis. Menurut Kimery \& McCard (Ling, Chai, \& Piew, 2010) kepercayaan didefinisikan sebagai kesediaan customer untuk menerima kekurangan dalam transaksi online berdasarkan harapan positif mereka mengenai perilaku onlineshop di masa depan. Indikator yang digunakan adalah Security (Keamanan), Privacy (Privasi) dan Reliability (Reliabilitas).

\section{Purchase Decision}

Situasi dimana manusia kehabisan alternatif untuk memilih sebuah keputusan sangatlah jarang terjadi (Schiffman, Kanuk, \& Hansen, 2012). Hal tersebut disebabkan karena sekarang ini kebebasan suatu individu untuk memilih tercermin melalui industri-industri yang menyediakan berbagai variasi produk. Jika terpapar banyak pilihan di seluruh penjuru, mustahil bagi konsumen apabila tidak mempunyai beberapa alternatif. Prinsip umumnya, konsumen mengambil suatu keputusan jika ditawarkan beberapa pilihan). Dalam penelitian ini indikator yang digunakan adalah: Problem Recognition (Pengenalan Masalah), Information Search (Pencarian Informasi), Evaluation of Alternatives (Evaluasi Alternatif), Product Choice (Keputusan Pembelian Produk), dan Outcomes (Perilaku Sesudah Pembelian).

\section{METODE PENELITIAN}

\section{MetodeAnalisis Data}

Metode yang digunakan pada penelitian ini adalah analisis Jalur SEM menggunakan Amos.
Pendekatan Structural Equation Modelling (SEM) ini digunakan karena mampu menghasilkan analisis yang lebih komprehensif sesuai dengan kerangka pemikiran yang dibentuk oleh peneliti

\section{Tempat dan Waktu Penelitian}

Penelitian ini akan dilakukan pada bulan MeiJuli 2020 dan dilaksanakan di Jabodetabek.

\section{Responden Penelitian}

Dalam penelitian ini populasi merupakan konsumen E-commerce tiket travel dan reservasi hotel. Sampel yang di uji adalah responden yang telah melakukan transaksi pada layanan jasa tiket travel dan reservasi hotel online (Traveloka.com, Tiket.com dan Pegipegi.com) dalam kurun waktu 3 bulan terakhir di wilayah Jakarta, Bogor, Depok, Tangerang dan Bekasi. Ukuran sampel minimum yang diperlukan untuk mengurangi bias pada semua jenis estimasi SEM adalah 200 (Loehlin, 1998) digunakan sebagai penentu ukuran sampel penelitian ini sehingga ditentukan jumlah responden sebanyak 200 orang.

\section{HASIL DAN PEMBAHASAN}

\section{Analisis Deskriptif Responden:}

Dari penelitian ini diperoleh karakteristik 200 reponden yang ada adalah sebagai berikut: (Tabel 1) dimana terlihat bahwa: mayoritas responden berada di Jakarta (28\%), mempunyai alasan menggunakan aplikasi travel online karena adanya harga dan promo yang ditawarkan $(70 \%)$, mengetahui layanan jasa tiket online melalui media elektronik (65\%), dengan layanan yang dipesan adalah tiket pesawat (64\%), mengeluarkan budget untuk tiket 1-3 juta (44\%) serta lebih prefer membayar melalui system ATM (54\%) merekapun mayoritas mengetahui promo yang ada melalui media social $(53 \%)$ 


\section{Analisis Inferensial:}

\section{Model Diagram Jalur}

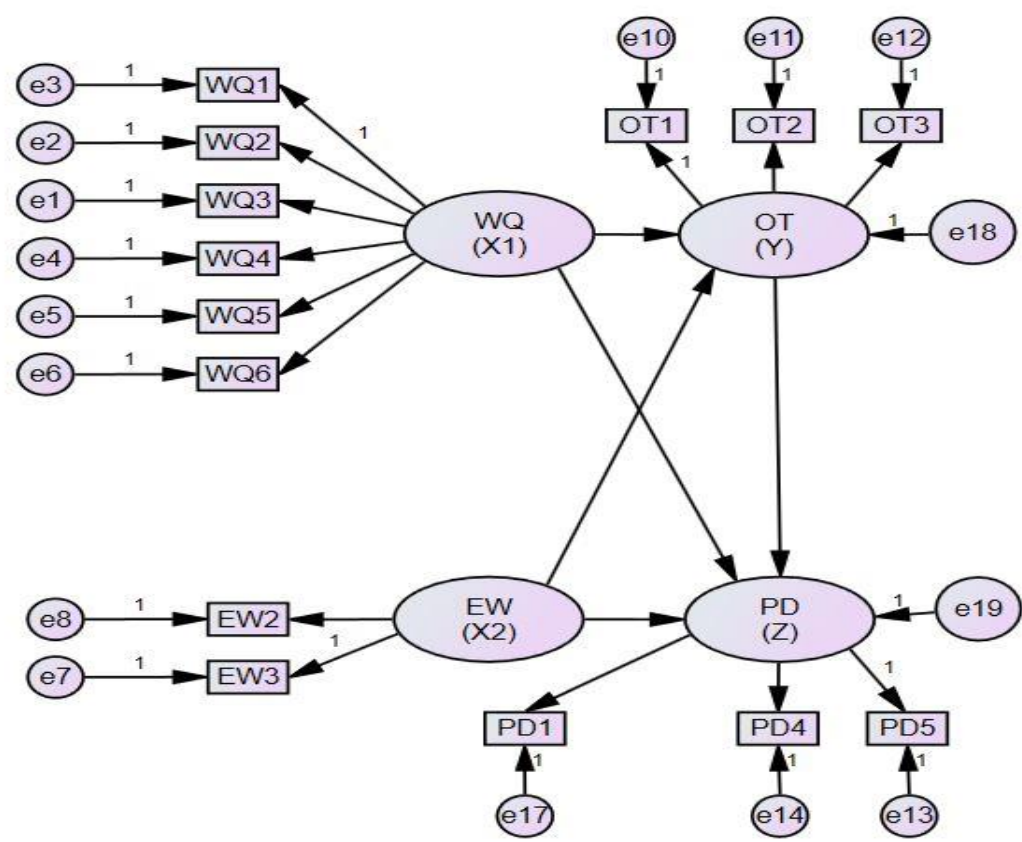

Gambar 1: Model Diagram Jalur Pengaruh Variabel website quality (X1), EWOM (X2), variabel purchase decision (Z), dan variabel online trust $(\mathrm{Y})$ yang Didasarkan Teori.

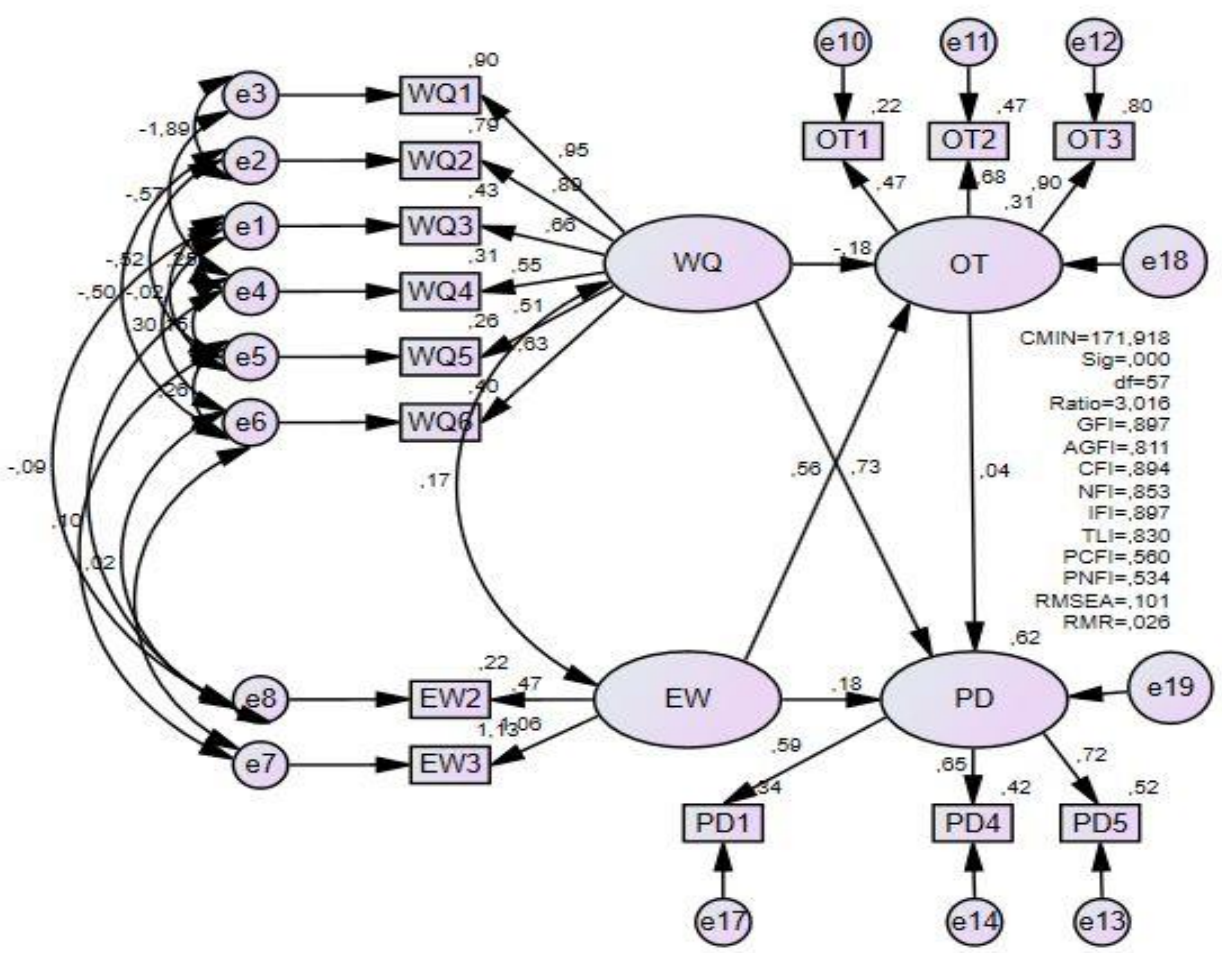

Gambar 2: Overall Structure Model. 


\section{Persamaan Struktural}

\section{Persamaan Sub Structural:}

Online Trust $(\mathrm{Y})=\beta 1$ Web Quality $(\mathrm{X} 1)+\beta 2$ $\operatorname{EWOM}(\mathrm{X} 2)+\delta 1$

Purchase Decision $(\mathrm{Z})=\beta 3$ Online Trust $(\mathrm{Y})+$ $\beta 1$ Web Quality (X1) $+\beta 2$ EWOM $(\mathrm{X} 2)+\delta 1$

\section{Persamaan Structural:}

Purchase Decision $(Z)=\beta 1$ Web Quality $(X 1)+$ $\beta 2$ EWOM (X2) $+\beta 3$ Online Trust $(\mathrm{Y})+\delta 1$

Dari hasil pengolahan SEM melalui Amos pada struktur keseluruhan layanan jasa tiket travel dan reservasi hotel online (Traveloka.com, Tiket.com dan Pegipegi.com). Diperoleh hasil Overall Structure Model pada Gambar 2.

Data penelitian telah mendapatkan modifikasi indeks. Dimana model ini mendapatkan hasil (default model) 'minimum was achieved' yang ditunjukkan dengan oleh Chi-square $=171.918$, Degrees of freedom $=57$ dan Probability level $=0.000$. Hasil ini menunjukkan bahwa secara keseluruhan model telah sesuai dengan data sampel meskipun probability $=0.00$. Sedangkan hasil uji goodness of fit full model penelitian ini dapat dilihat pada Tabel 1.

Tabel 1. GOF Full Model

\begin{tabular}{|c|c|c|c|}
\hline $\begin{array}{c}\text { Ukuran } \\
\text { Kecocokan } \\
\text { Keseluruhan } \\
\text { Model }\end{array}$ & $\begin{array}{c}\text { Hasil } \\
\text { Perhitungan }\end{array}$ & Syarat & Keterangan \\
\hline \multicolumn{4}{|l|}{ Absolute fit Model } \\
\hline $\begin{array}{l}\text { Root Mean } \\
\text { Square Error of } \\
\text { Approximation } \\
\text { (RMSEA) }\end{array}$ & 0,101 & $\leq 0,08$ & $\begin{array}{c}\text { Good of } \\
\text { Fit }\end{array}$ \\
\hline $\begin{array}{l}\text { Goodness of Fit } \\
\text { Index (GFI) }\end{array}$ & 0,897 & $\begin{array}{c}\geq \\
0,90\end{array}$ & $\begin{array}{c}\text { Good of } \\
\text { Fit }\end{array}$ \\
\hline \multicolumn{4}{|c|}{ Incremental Fit Model } \\
\hline $\begin{array}{l}\text { Comparative Fit } \\
\text { Index (CFI) }\end{array}$ & 0,894 & $\geq 0,90$ & $\begin{array}{c}\text { Good of } \\
\text { Fit }\end{array}$ \\
\hline $\begin{array}{l}\text { Normed Fit } \\
\text { Index (NFI) }\end{array}$ & 0,853 & $\geq 0,90$ & $\begin{array}{c}\text { Marginal } \\
\text { Good }\end{array}$ \\
\hline $\begin{array}{l}\text { Incremental Fit } \\
\text { Index (IFI) }\end{array}$ & 0,897 & $\geq 0,90$ & $\begin{array}{c}\text { Good of } \\
\text { Fit }\end{array}$ \\
\hline \multicolumn{4}{|c|}{ Parsimonious Fit Model } \\
\hline $\begin{array}{l}\text { Adjusted } \\
\text { Goodness of Fit } \\
\text { Index (AGFI) }\end{array}$ & 0,811 & $\geq 0,90$ & $\begin{array}{l}\text { Marginal } \\
\text { Good }\end{array}$ \\
\hline
\end{tabular}

Sumber: Pengolahan data (2019)
Hasil uji fit model yang ditunjukkan oleh Tabel 1 menunjukkan pengukuran model kecocokan absolut, hasil perhitungan menunjukkan RMSEA $=0,101$ dan GFI $=0,897$, dengan demikian dapat disimpulkan bahwa model yang dibuat berada pada kategori baik. Sementara untuk pengukuran model kecocokan incremental, hasil perhitungan menunjukkan nilai $\mathrm{CFI}=0,994$, NFI $=0,853$ dan $\mathrm{IFI}=0,897$, sehingga dari temuan ini dapat disimpulkan bahwa model yang dianalisis berada pada kriteria baik. Demikian juga mengenai pengukuran model kecocokan parsimoni, hasil perhitungan menunjukkan bahwa angka AGFI sebesar 0,811 , sehingga dapat dikatakan pula bahwa model yang dianalisis berada pada kategori baik.

Sehingga disimpulkan bahwa analisis goodness of fit full model diatas telah fit. Meningat sebagian besar parameter pengujian telah terpenuhi sesuai dengan data empiris.

Guna menguji besaran pengaruh konstruk, konstruk terhadap dimensi dan dimensi terhadap indikator, standardized Regression Weight digunakan sebagai berikut.

Tabel 2. Standardized Regression Weight

\begin{tabular}{lclc}
\hline OT & $<---$ & WQ &,- 175 \\
\hline OT & $<---$ & EW &, 564 \\
\hline PD & $<--$ & OT &, 041 \\
\hline PD & $<---$ & WQ &, 733 \\
\hline PD & $<---$ & EW &, 182 \\
\hline WQ3 & $<---$ & WQ &, 656 \\
\hline WQ2 & $<---$ & WQ &, 886 \\
\hline WQ1 & $<---$ & WQ &, 948 \\
\hline WQ4 & $<---$ & WQ &, 554 \\
\hline WQ5 & $<---$ & WQ &, 512 \\
\hline WQ6 & $<---$ & WQ &, 629 \\
\hline EW3 & $<---$ & EW &, 964 \\
\hline EW2 & $<---$ & EW &, 470 \\
\hline OT1 & $<---$ & OT &, 473 \\
\hline OT2 & $<---$ & OT &, 684 \\
\hline OT3 & $<---$ & OT &, 896 \\
\hline PD4 & $<---$ & PD &, 648 \\
\hline PD1 & $<---$ & PD &, 585 \\
\hline PD5 & $<---$ & PD &, 720 \\
\hline
\end{tabular}


Dari table Tabel 2 Standardized Regression Weight mendapatkan gambaran bahwa hubungan antar konstruk sangat baik pada hubungan dua variable yang lebih dari 0,50 yaitu hubungan Web Quality (X1) dengan Purchase Decision (Z) dan hubungan EWOM (X2) dengan Online Trust (Y). Sementara sisanya dibawah 0,50. Berdasarkan estimasi dari Tabel 2 dapat disusun permodelan regresi sub struktural dan struktural sebagai berikut:

\section{Persamaan Sub Struktural:}

Online Trust $(\mathrm{Y})=(-0,175)$ Web Quality $(\mathrm{X} 1)+$

$$
(0,564) \operatorname{EWOM}(\mathrm{X} 2)+\delta 1
$$

Purchase Decision $(\mathrm{Z})=(0,41)$ Online Trust $(\mathrm{Y})$ $+(0,733)$ Web Quality (X1) + $(0,182)$ EWOM $(X 2)+0,06$

\section{Persamaan Struktural:}

Purchase Decision $(\mathrm{Z})=(0,41)$ Online Trust $(\mathrm{Y})$ $+(0,733)$ Web Quality (X1) + $(0,182)$ EWOM $(X 2)+0,06$

Hasil summary besarnya pengaruh antar variabel tertuang dalam Tabel 3 .

Tabel 3. Rekapitulasi Pengaruh Antar Variabel

\begin{tabular}{clllllll}
\hline No & Variabel & & & Estimated & PL & PTL & Total \\
\hline $\mathbf{1}$ & WQ & $\rightarrow$ & OT & 0,072 & 0,072 & & 0,072 \\
\hline $\mathbf{2}$ & EWOM & $\rightarrow$ & OT & 0,212 & 0,212 & & 0,212 \\
\hline $\mathbf{3}$ & WQ & $\rightarrow$ & PD & 0,114 & 0,114 & 0,114 \\
\hline $\mathbf{4}$ & EWOM & $\rightarrow$ & PD & 0,069 & 0,069 & & 0,069 \\
\hline $\mathbf{5}$ & OT & $\rightarrow$ & PD & 0,052 & 0,052 & & 0,052 \\
\hline $\mathbf{6}$ & WQ & $\rightarrow$ & PD & & 0,114 & 0,052 & 0,0059 \\
\hline $\mathbf{7}$ & EWOM & $\rightarrow$ & PD & & 0,069 & 0,052 & 0,0035 \\
\hline
\end{tabular}

\section{Pembahasan}

Dari hasil penelitian yang telah dilaksanakan diperoleh analisa bahwa pada E-commerce Tiket Travel dan Reservasi Hotel di Indonesia, Web Quality (X1) serta EWOM (X2) berpengaruh terhadap Online Trust (Y). Bila ditelaah lebih mendalam maka terlihat bahwa pengaruh indikator informasi (WQ1) yang terdapat dalam variabel Web Quality sangat dominan mempengaruhi responden untuk menumbuhkan kepercayaan tersebut. Kelengkapan dan detail informasi menjadi satu faktor yang sangat berpengaruh. Karena dari kelangkapan dan keakuratan informasi ini lah kepercayaan terhadap ecommerce dapat dibangun konumen. Demikian juga dengan indikator Konten (EW3) pada variable EWOM sangat mempengaruhi responden dalam meningkatkan kepercayaan secara online tersebut. Konten ini menyatakan kesesuaian review dengan harapan yang dimiliki responden. Dengan makin maraknya ecommerce, testimony adalah sumber lain yang bisa dimanfaatkan konsumen untuk melakukan check dan recheck atas kinerja sebuah ecommerce. Sangat vital bagi calon konsumen untuk mencari referensi dan rekomendasi sebelum dirinya melakukan transaksi. Yang mengejutkan pada penelitian ini adalah justru indikator keamanan dalam web quality kecil dalam memberikan pengaruh, hal ini memberikan analisis bahwa keamanan masih menjadi pertimbangan tersendiri responden untuk percaya secara online. Hal ini sesuai dengan penelitian yang menemukan bahwa banyak faktor-faktor yang menyebabkan pelanggan untuk tidak menggunakan $e$ commerce, yaitu masalah risiko, yang umumnya terkait seputar keamanan dalam pembayaran, ketakutan akan penipuan, ataupun kualitas barang yang tidak sesuai ekspektasi (Kotler \& Keller, 2016).

Lebih jauh bisa dianalisis bahwa Online Trust (Y) yang ada dalam penelitian ini sama sekali tidak mempengaruhi Purchase Decision (Z) responden. Ternyata meskipun E-commerce Tiket Travel dan Reservasi Hotel di Indonesia memiliki Web Quality dan EWOM yang mampu untuk meningkatkan kepercayaan online responden. Terlihat indikator keamanan yang memberikan pengaruh terkecil dalam variable Online Trust (Y) dalam menciptakan Purchase Decision (Z). sehingga jelas bahwa masalah keamanan masih merupakan issue terbesar bagi responden untuk melakukan Purchase Decision.

Namun demikian dalam penelitian ini ditemukan hal menarik dimana Web Quality (X1) ternyata secara langsung mempengaruhi Purchase Decision (Z). terlihat bahwa Indikator informasi (WQ1) pada variabel Web Quality (X1) cukup besar memberikan pengaruh sehingga pada Outcome (PD5) cukup besar pula mempengaruhi variable Purchase Decision (Z). Dari sini bisa dianalisis bahwa responden terlihat sangat puas dengan adanya kualitas informasi yang ada pada web tersebut sehingga faktor ini yang memungkinkan adanya pengaruh 
langsung terhadap Purchase Descision tanpa mempertimbangkan adanya faktor keamanan yang menjadi kendala munculnya trust yang ada pada mereka.

\section{KESIMPULAN}

Dari penelitian ini disimpulkan bahwa Purchace Decision hanya dipengaruhi secara langsung oleh Web Quality. Sementara Online Trust dipengaruhi secara langsung oleh Web Quality dan EWOM meskipun demikian tidak ada pengaruh langsung Online Trust terhadap Purchace Decision. Disinipun tidak terdapat pengaruh tidak langsung Web Quality dan EWOM terhadap Purchace Decision melalui Online Trust.

Implikasi dari penelitian ini adalah bahwa $e$ commerce tiket dan hotel online perlu mempertahankan kualitas informasi baik reabilitas dan detail informasi yang tersedia mengingat inilah indikator yang paling mempengaruhi dan memberikan outcome berupa kepuasan bagi konsumen saat mereka melakukan Purchase Decision.

E-commerce tiket dan hotel online perlu untuk meningkatkan indikator keamanan dalam webnya karena hal ini merupakan pertimbangan negative tersendiri bagi konsumen dalam mempengaruhi keputusan pembeliannya.

\section{REFERENSI}

Gilliland, N. (2017, Agustus 17). Five examples of brands that succeed with word-of-mouth marketing. Retrieved from https://econsultancy.com/:

https://econsultancy.com/brands-succeedword-of-mouth-marketing/

KEG. (2018, Juni 23). 30 Juta Perjalanan Wisatawan Nusantara di Momen Mudik Lebaran Gairahkan Industri Pariwisata. Retrieved from Wonderful Indonesia CoBranding Forum: https://swa.co.id/wicf/news/30-jutaperjalanan-wisatawan-nusantara-di-momenmudik-lebaran-gairahkan-industripariwisata
Kotler, \& Keller. (2016). Marketing Management. 15th. America: Pearson Education Limited.

Ling, K. C., Chai, L. T., \& Piew, T. H. (2010). The Effects of Shopping Orientations, Online Trust and Prior Online Experience toward Customers Online Purchase Intention. Internatinal Business Research, Vol 3 No 3.

Loehlin, J. C. (1998). Latent Variable Models: An Introduction to Factor, Path, and Stuctural Analysis. Mahwah NJ: Lawrence Erlbaum.

Nasiruddin, Kauthar, Hashim, H., \& Yusof, R. N. (2016). Electronic Word of Mouth: Exploring the Consumer Perspective. International Journal of Accounting and Business Management, Volume 4 Nomor 2.

Sastika, W. (2016, 18 - 19 Maret). Analisis Pengaruh Kualitas Website (Webqual 4.0) Terhadap Keputusan Pembelian pada Website E-Commerce Traveloka (Studi Kasus: Pengguna Traveloka di Kota Bandung Tahun 2015). Seminar Nasional Teknologi Informasi dan Komunikasi. Yogyakarta.

Schiffman, L. G., Kanuk, L. L., \& Hansen, H. (2012). Consumer behaviour: a European outlook. Newyork: Pearson Financial.

Setyawan, Y. N., \& Japarianto, E. (2014). Analisa Pengaruh Kepercayaan, Jaminan Rasa Aman, dan Aksestabilitas terhadap Minat Menabung Nasabah Bank Danamon Surabaya. Jurnal Manajemen Pemasaran, Vol 2 No 1.

Sugianto, Y. M. (2016). Pengaruh Website Quality, Electronic- Word-of-Mouth dan Sales Promotion Terhadap Impulse Buying pada Zalora. Jurnal Manajemen Pemasaran, Volume 3 No 2. 